\title{
Policy perspectives on expanding cogeneration from bagasse in Malawi
}

\author{
Long Seng To $^{1 *}$, Kingdom Kwapata ${ }^{2}$, Leonard Masala ${ }^{2}$, \\ Virginia Alonso Navarro ${ }^{1}$, Simon Batchelor ${ }^{3}$, Yacob Mulugetta ${ }^{1}$, \\ Andrew Barnett ${ }^{4}$, Stephen Karekezi ${ }^{5}$ \\ 1 Department of Science, Technology, Engineering and Public Policy, University College London, 2nd Floor, \\ Boston House, 36-38 Fitzroy Square, London W1T 6EY, United Kingdom \\ 2 Lilongwe University of Agriculture and Natural Resources, PO Box 219, Lilongwe, Malawi \\ 3 Gamos Ltd., 231 Kings Road, Reading, Berkshire RG1 4LS, United Kingdom \\ 4 The Policy Practice Ltd., 33 Southdown Avenue, Brighton BN1 6EH, United Kingdom \\ 5 Africa Energy Policy Research Network (AFREPREN/FWD), PO Box 30979-00100 GPO, Nairobi, Kenya
}

\begin{abstract}
Agro-industries have the potential to make a substantial contribution to sustainable energy supply in Africa, including energy access in rural areas. This paper focuses on the drivers and barriers to wider use of cogeneration from sugarcane bagasse in Malawi as there is a potential for the technology to enable access to electricity in rural areas. The paper gives an overview of the policy landscape for the energy sector and the sugar industry in Malawi. The research involved site visits, focus group discussions, and individual semi-structured interviews with participants from key government departments, businesses, research institutes and international agencies. It was found that energy sector reform, the proposed feed-in tariff for renewable energy, and risk are the key issues for investment in this area.
\end{abstract}

Keywords: biomass, renewable energy, electricity

Journal of Energy in Southern Africa 28(1): 45-53

DOI: http://dx.doi.org/10.17159/2413-3051/2017/v28i1a1420

Published by the Energy Research Centre, University of Cape Town ISSN: 2413-3051 http://journals.assaf.org.za/jesa

Sponsored by the Department of Science and Technology

\footnotetext{
* Corresponding author: Tel: +44 (0)20 31089750

Email:1.to@ucl.ac.uk
} 


\section{Introduction}

Global discourses around energy, development and sustainability are mobilising new technical and financial resources for clean energy initiatives in developing countries. Major global agreements on climate change (under the United Nations Framework Convention on Climate Change (UNFCCC)) and development goals (at the United Nations Summit on the Post-2015 Development Agenda) were announced in 2015. The United Nations has also launched the Decade for Sustainable Energy for All (2014-2024), which brings together government, private sector and civil society in an effort to provide universal energy access, to double the rate of global energy efficiency improvement, and to double the share of renewable energy in the global energy mix (UN General Assembly, 2012). International organisations, development banks, and bilateral aid programs all have growing clean energy portfolios. Global climate finance was estimated to be USD 331 billion (Buchner et al., 2014) and renewable energy investment was about USD 214 billion worldwide in 2014 (Frankfurt School-UNEP Centre/BNEF, 2014).

One promising approach for realising these ambitious goals for sustainable development in Africa is the involvement of agro-industries (such as sugar, tea and coffee estates) in creating clean energy projects to enable energy access in their surrounding rural areas. Agricultural production and agro-industries contribute around $45 \%$ of the economy of sub-Saharan Africa (Byerlee et al., 2013). Agro-industries utilise energy for processing and business operations, and some also provide energy services for employees living in surrounding areas. Across the five sub-Saharan countries of Malawi, Kenya, Uganda, Ethiopia and Tanzania there is an estimated $313 \mathrm{MW}$ of installed power capacity in agro-industries, including $270 \mathrm{MW}$ from bagasse cogeneration (Karekezi, 2016). Investment in clean energy in agro-industries can reduce energy costs while improving energy access, energy security and grid stability. There are also a number of co-benefits, including: improved economic performance of plants; new business opportunities; job creation; reduction in indoor air pollution; poverty alleviation; increased wellbeing and productivity; increased capabilities and skills; enhanced innovation systems; and reduction in greenhouse gas emissions (Masera and Couture, 2015).

Policies are needed to encourage the use of clean energy in agro-industries. These policies need to be incorporated into a coherent national regulatory framework in order to capture the multiple benefits of the investment and to provide a stable investment environment. Previous studies have examined the influence of policy and regulatory instruments on the advancement of renewable energy (for example Byrnes et al., 2013; GNESD,
2007; Luthra et al., 2015; Yaqoot et al., 2016). There is, however, limited understanding of specific barriers and opportunities for agro-industries. This investigation examines the policy landscape and stakeholder perspectives for energy and agro-industries in Malawi. It will focus on cogeneration in the sugar industry, an important agro-industry in Malawi and other parts of sub-Saharan Africa (Hassan, 2008). Cogeneration is a well-established clean energy technology which has been widely deployed in emerging economies such as Brazil and India (Maltsoglou et al., 2013). Fieldwork conducted for this paper included visits to agro-industry facilities, interviews and focus group discussions with key stakeholders from government, industry and academia in February 2015 and February 2016.

Section 2 discusses the energy situation and evolution of energy policy in Malawi. Section 3 discusses the agro-industry sector and policies. Section 4 maps the key stakeholders and their viewpoints on what is needed in order to scale-up the use of clean energy in agro-industries in Malawi. Section 5 concludes the paper and identifies gaps in the current energy and climate change discourse and discusses how global initiatives can contribute to national development goals.

\section{Energy}

\subsection{The energy situation in Malawi}

This section sets out trends for the energy sector in Malawi. The most recent energy consumption study of the country was conducted in 2008 and showed that it had a low level of energy consumption, with an annual per capita energy consumption of 11.4 GJ/year. In comparison, the per capita average energy consumption in upper-middle-income countries was $80 \mathrm{GJ}$ and in high-income countries over 200 GJ. Table 1 shows that households account for over $80 \%$ of the energy demand and that biomass (in the form of fuelwood, charcoal, crop residue and ethanol) supplies almost $90 \%$ of the energy in Malawi. Two critical observations can be made from this picture. Firstly, it shows that Malawi's energy system represents an economy that relies heavily on subsistence agriculture, with little energy input in the key productive sectors such as industry and agriculture. Second, it reflects the high dependence of households on traditional biomass, which has led to the demand for wood exceeding sustainable supply levels by 3.7 million tons annually (Zalengera et al., 2014).

Malawi's current installed electricity generation capacity is $351 \mathrm{MW}$ (Mhango, 2015), which mainly consists of hydropower plants along the Shire River $(98 \%)$ in the south of the country (Zalengera et al., 2014). These are owned by the state-owned Electricity Supply Corporation of Malawi (Escom). Electricity access is very low at $9 \%$ nationally and 
Table 1: Total energy demand by sector and fuel in Malawi in 2008 (Government of Malawi, 2009).

\begin{tabular}{lccccc}
\hline Sector & & \multicolumn{2}{c}{ Energy demand by fuel type (TJ/yr) } \\
& Biomass & Coal & Electricity & Petroleum & Total \\
\hline Household & 127574 & 5 & 1798 & 672 & $130049(83.2 \%)$ \\
Industry & 10004 & 3481 & 2010 & 3130 & $18625(11.9 \%)$ \\
Transport & 270 & 15 & 35 & 5640 & $5960(3.8 \%)$ \\
Service & 452 & 174 & 477 & 558 & $1661(1.1 \%)$ \\
Total & $138300(89.5 \%)$ & $3675(2.4 \%)$ & $4320(2.8 \%)$ & $10000(6.4 \%)$ & $156295(100 \%)$
\end{tabular}

$1 \%$ in rural areas (Mhango, 2015). However, even those with access to the electricity grid experience frequent power cuts and load-shedding, a situation which is likely to worsen, as projected demand is expected to increase sharply, with no new power installations planned (see Figure 1). The aging generation, transmission and distribution infrastructure experiences high technical losses and needs frequent maintenance (Taulo et al., 2015). About 18$22 \%$ of the electricity generated is lost due to technical inefficiencies in the transmission and distribution network (Gamula et al., 2013). As part of the longer-term solution, there are plans to connect Malawi to the Southern African Power Pool (SAPP) through an interconnector with Mozambique (SAPP, 2015).

Malawi has abundant coal resources and produces approximately 133000 tonnes of coal per annum. The country has about 20 million tonnes of proven reserves and an estimated reserve of about 80 million tonnes. Demand for coal from industry currently exceeds domestic production and the remainder is imported from Mozambique (Government of Malawi, 2009; Zalengera et al., 2014). Coal is mainly used for industrial heat, and not generally used by households. Electricity generation from coal has been considered by the government and feasibility studies have been carried out (Gamula et al., 2013). Malawi has no known oil reserves, and petroleum products are imported via Tanzania, Mozambique and South Africa and trans- port costs for fuels are very high. This dependence on imported fuels leaves the country highly vulnerable to changes in oil price and currency fluctuations (Taulo et al., 2015). Malawi has excellent renewable energy resources, especially solar energy, biomass and hydropower (see Table 2). Outside of large hydroelectricity, cogeneration from bagasse is one of the largest contributors to renewable energybased electricity in Malawi's total installed power generation capacity. Malawi has not been able to benefit from climate financing and does not have any projects registered under the clean development mechanism, due to a number of technical, financial and regulatory challenges (Chirambo, 2016).

\subsection{Energy policy}

Policy framework

Energy is considered to be an important driver of Malawi's overall development goal. The country's long-term development plan, Malawi Vision 2020, includes goals for promoting efficient electricity supply and distribution, improving the supply of petroleum products, and reducing dependence on fuelwood, as key strategic steps in developing economic infrastructure (National Economic Council, 1998). Energy is also one of the top priorities in medium-term plans, the Malawi Growth and Development Strategy II (2011-2016). The strategy identifies low energy-generation capacity in Malawi as a major constraint to industrial development

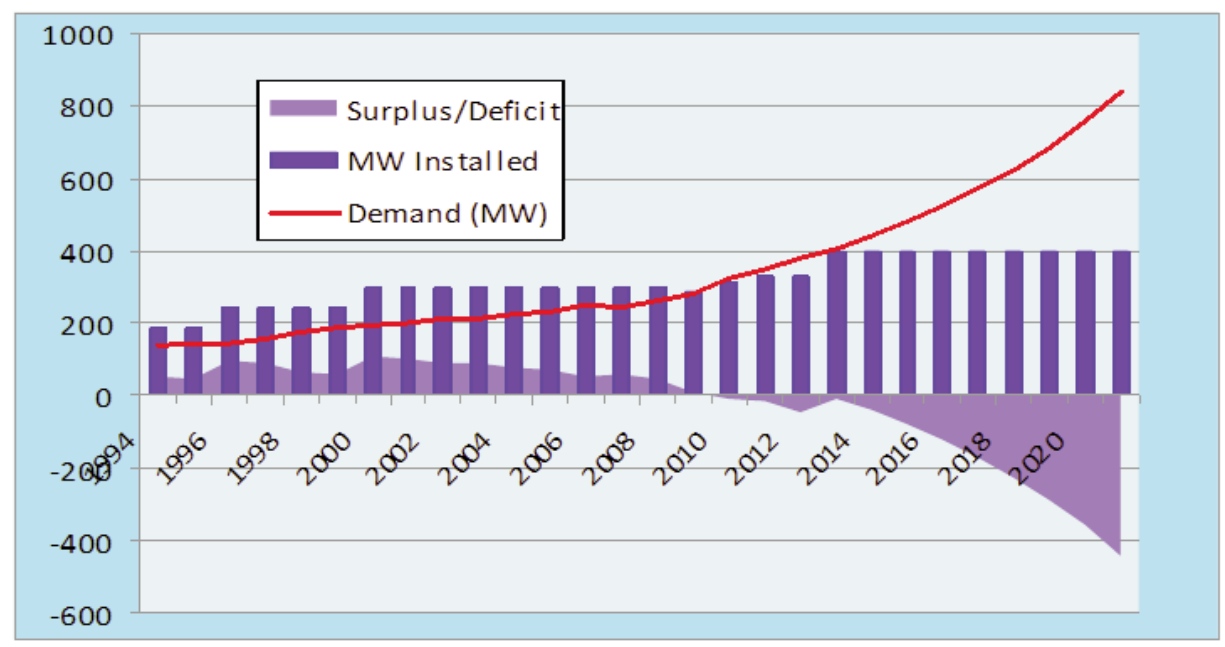

Figure 1: Projected demand vs supply growth in power generation in Malawi (Mhango, 2015). 
Table 2: Renewable energy potential and installed capacity in Malawi (IRENA, 2016; Taulo et al., 2015).

\begin{tabular}{|c|c|c|}
\hline Source & Theoretical potential & Installed capacity \\
\hline Large hydro & $1670 \mathrm{MW}$ or $15000 \mathrm{GWh} / \mathrm{yr}$ & $351 \mathrm{MW}$ \\
\hline Micro-hydro & $150 \mathrm{MW}$ & $4.5 \mathrm{MW}$ \\
\hline Solar & $356284837 \mathrm{MWh} / \mathrm{yr}$ & $\begin{array}{l}4855 \mathrm{~m}^{2} \text { of solar hot water heaters } \\
165 \mathrm{~kW}_{\mathrm{p}} \text { of small solar photovoltaic systems } \\
870 \mathrm{~kW}_{\mathrm{p}} \text { of large solar photovoltaic systems }\end{array}$ \\
\hline Wind & $\begin{array}{l}\text { Wind atlas currently being compiled by govern- } \\
\text { ment; preliminary results indicate wind limited } \\
\text { due to comparatively low wind speeds of } 2-7 \mathrm{~m} / \mathrm{s}\end{array}$ & 6 community-scale wind-solar hybrid systems \\
\hline \multirow[t]{2}{*}{ Biomass } & 0.1-0.5 EJ/yr, comprising: & Widespread use of traditional fuelwood \\
\hline & $\begin{array}{l}161910 \mathrm{TJ} / \mathrm{yr} \text { crop residues, } \\
48744 \mathrm{TJ} / \mathrm{yr} \text { forest residues, } \\
1100 \mathrm{GWh} / \mathrm{yr} \text { biogas from animal manure }\end{array}$ & $\begin{array}{l}18 \mathrm{MW}_{e} \text { of bagasse based electricity generation } \\
18 \mathrm{~m} \mathrm{~L} / \mathrm{yr} \text { of molasses-based ethanol production }\end{array}$ \\
\hline Geothermal & $200 \mathrm{MW}_{e}$ & Plans to build $30 \mathrm{MW}$ plant \\
\hline
\end{tabular}

(Ministry of Finance and Development Planning, 2012). The National Energy Policy for Malawi (Ministry of Energy and Mining, 2003) gave rise to the following legislation in 2004:

- The Energy Regulation Act established the Malawi Energy Regulatory Authority (MERA), which oversees the electricity, liquid fuel and gaseous fuel markets, including technical regulations and pricing.

- The Rural Electrification Act established the Rural Electrification Fund.

- The Electricity Act permitted private investment in the electricity sector.

- The Liquid Fuels and Gas (Production and Supply) Act regulates liquid fuels and gas production licensing, safety, pricing, taxation and the strategic reserve.

Implementation of these acts was supported by the promulgation of a number of regulations and by-laws in 2008. The Escom has focused on increasing the number of power connections in urban areas, while the rural electrification programme has been implemented by the Department of Energy Affairs (Mhango, 2015). 2008 also saw the development the Biomass Energy Strategy (BEST) which aims to ensure sustainable supply of biomass energy, promote access to efficient biomass combustion technologies and create the institutional capacity required to effectively manage the biomass energy sector.

\section{Electricity}

Reform of the electricity sector is currently underway in Malawi. The Public Sector Reform was launched in 2015, which included a commitment to unbundle electricity generation from transmission and distribution functions. In July 2016, parliament passed a new electricity bill that unbundles Escom into separate entities for generation, transmission and distribution of electricity. This would allow new companies to enter the power sector for generation and selling power to Escom. In the future, Escom will have the mandate to buy and distribute electricity power to different parts of Malawi and also import or export electric power to and from other countries (Gwede, 2016). The development might lead to the reduction of power outages in Malawi and increase power generation in the country (Malawi Voice, 2016).

Major international projects to support the electricity sector include the Power Sector Revitalisation Project, Malawi Compact funded by the USA's Millennium Challenge Corporation that supports infrastructure development as well as power sector reform (Malawi Compact, n.d.). The World Bank also provides support for strengthening and expanding the electricity network, generation and transmission feasibility studies, demand-side management and energy efficiency measures, capacity building and technical assistance, through the Energy Sector Support Project World Bank, 2011). A feed-in tariff for renewable energy generated electricity is currently being introduced in Malawi to encourage investment from the private sector. The proposed tariffs for firm and non-firm power are shown in Table 3 (firm power is energy that is guaranteed to be available at a given time).

Table 3: Proposed feed-in tariff in Malawi (Zalengera et al., 2014).

\begin{tabular}{lcc}
\hline Technology & $\begin{array}{c}\text { Feed-in tariff } \\
\text { for firm power } \\
\text { (USD/kWh) }\end{array}$ & $\begin{array}{c}\text { Feed-in tariff for } \\
\text { non-firm power } \\
\text { (USD/kWh) }\end{array}$ \\
\hline Solar photovoltaic (PV) & 0.20 & 0.10 \\
Wind & 0.13 & 0.13 \\
Small hydro & $0.10-0.13$ & $0.08-0.12$ \\
Biomass (incl. biogas) & 0.08 & 0.10 \\
Geothermal & 0.105 & 0.105
\end{tabular}




\section{Liquid fuels}

The high cost of transporting petroleum to the country led the government to support ethanol fuel blending (Government of Malawi, 2009). Ethanol is widely produced in the region, with Zimbabwe, Swaziland, Kenya, Sudan, Tanzania, Uganda and Ethiopia as producers. Malawi is the only country where petrol-ethanol blending has been continually practised since 1982 (Amigun et al., 2011), although in varying quantities (Steingass et al., 1988). In addition, MERA is reviewing the current ethanol-petrol blending ratio with a possibility of increasing it from 10:90 to 20:80 (Lapukeni, 2013). Malawi's Department of Science and Technology, in collaboration with the privately owned distillery Ethanol Company, is further promoting the importing of 'flexi-fuel' vehicles from Brazil that run on $85 \%$ ethanol. The government is, therefore, supportive of private sector investments in the production, distribution and marketing of ethanol.

\section{The sugar industry}

Malawi's economy is based on agriculture, which accounts for more than $80 \%$ of export earnings and contributes $36 \%$ of gross domestic product, and supports the livelihood of $85 \%$ of the population (Mwase et al., 2013). Smallholder farmers contribute $75 \%$ of agricultural production (Mwase et al., 2013). Global sugar production and trade was highly regulated with tariffs, quotas and multilateral agreements the most important for Malawi was the sugar regime of the European Union (EU) (Phillips, 2014). This consisted of guaranteed high internal prices, production quotas for each member state, tariffs on sugar imports, and export subsidies designed to protect sugar beet growers in the EU. Since 1975, African, Caribbean and Pacific (APC) regions, including Malawi, received preferential terms for sugar export to the EU. The EU's Sugar Protocol allowed the EU to buy a fixed quantity of sugar from APC producers at its internal price (Panagariya, 2002). The EU moved to reform its sugar regime in recent years because of a ruling by the World Trade Organisation. The first round of reforms in 2006 reduced the price of sugar in the EU by $36 \%$ over four years, which meant reduced revenues for Malawian sugar producers (Hudson, 2006). Further reform of the sugar regime is set to abolish quotas, guarantee internal price and export limits (Terazono, 2014). Although Malawi will be affected by these reforms, it is relatively well placed to cope with the changes because Malawi's sugar industry has low costs and access to alternative markets (LMC International and Overseas Development Institute, 2012).

Malawi has two sugar factories, at Dwangwa in the central region and Nchalo in the southern region, with a current capacity of 300000 tons of sugar per annum. The factories are owned by Illovo
Sugar (Malawi), a public company listed on the Malawi Stock Exchange. The country produces an estimated average of 2.5 million tonnes of sugar per year, with over 950 tonnes of bagasse generated annually (Taulo et al., 2015). With the current two sugar mills that are able to generate electricity, there is the potential to generate up to $62 \mathrm{MW}_{e}$ of power, however, the equipment installed is only able to generate $18 \mathrm{MW}_{e}$ (Taulo et al., 2015; Zalengera et al., 2014). The electricity is mostly used for powering the sugar mills, agricultural activities for growing sugarcane, as well as homes and facilities for workers, but some power is also sold to surrounding industries such as ethanol plants and haulage companies. Electricity from bagasse is only available during cane-crushing season, for up to 200 days per year (UNEP, 2013).

Several new sugar schemes are currently being constructed, which could substantially increase electricity generation from bagasse in Malawi. A group of Malawian and British investors is setting up Limphasa Sugar Scheme in Nkhata Bay, and a local business group is establishing the Ntalimanja Sugar Scheme in Nkhotakota, while Illovo Sugar (Malawi) also plans to expand sugar production by 150000 tons per year (Federation of Southern African Sugar Producers, 2014). The governmentled Green Belt Initiative is also establishing a sugar factory in Salima, with an investment of USD 90 million, which is near completion and will, when fully operational, process 90000 tonnes of cane per year (Jimu, 2016).

\section{Stakeholder perspectives}

This section reports on the gaps and opportunities involved in scaling-up the use of clean energy in agro-industries, as identified by stakeholders during a workshop and follow-up interviews in Malawi in 2015 and 2016. The stakeholders included representatives from:

- the sugar industry, including sugarcane farmers, sugar mills and their owners;

- Malawian government departments which set the overall policy direction for energy, agriculture and development;

- financial institutions which provide financing for clean energy projects;

- multilateral and bilateral aid agencies and development banks, which can provide technical assistance and project finance;

- the electricity industry, which own the electricity generation and distribution infrastructure;

- knowledge institutions, such as universities, which provide the skills base for implementing the technology, as well as providing advice to government on policy issues; and

- civil society groups that work with smallholder sugarcane farmers.

The workshop involved presentations, plenary dis- 
cussions, and focus group discussions. Topics covered included energy and agricultural sector updates, clean energy options, enabling policies, and financial sustainability. For the focus group discussion, small groups of participants considered 14 statements related to agro-industries and energy in Malawi, indicating on a rating scale the degree to which they agreed or disagreed with them. Facilitators then led group discussions on the statements with the widest range of responses within the groups. Semi-structured interviews were conducted after the workshop to further explore the themes emerging from the workshop.

\subsection{Statistical analysis of statements}

The sample consisted of 17 key stakeholders across government, industry, civil society and knowledge institutions. Each person indicated their opinion on 14 statements related to bagasse cogeneration policy by marking an ' $\mathrm{X}$ ' on a line anchored by agree and disagree. The position of the mark was then measured in centimetres, with $0=$ 'agree' and 22.8 $=$ 'disagree' (and neutral therefore at 11.4). Table 4 shows the average responses of the stakeholders and that there was overall support for agro-industry involvement in improving energy access for local communities and enterprises (statement 13). However, stakeholders perceived a lack of political support for cogeneration (statement 14), a policy environment that was not conducive to scaling-up clean energy (statement 10), and Malawi lagging behind the Southern African Development Community (SADC) region in terms of green energy development (statement 11). Other barriers included insufficient biomass feedstock (statement 3 ), lack of skill capacity (statement 2), lack of domestic finance (statement 6) and difficulty accessing international finance (statement 7). Stakeholders agreed that cogeneration is a profitable additional revenue stream for agro-industries (statement 4) and that investment risk is not too high (statement 5). In addition, cogeneration technology was perceived as accessible in Malawi (statement 1). Stakeholders agreed that more open access to the electricity grid would also make investment in cogeneration more attractive (statement 12) and that if the levels of the proposed feed-in tariff for renewable energy electricity were set high enough, then cogeneration would be more widespread (statement 8) without affecting the ability of poor people to access electricity (statement 9). Statistical analysis showed that there were few differences in opinion between different kinds of stakeholders. A one-way analysis of variance showed that there were no statistically significant differences between the responses of different stakeholder groups (researchers, government, industry, civil society and knowledge institutions) for most of the statements except 'Malawi is lagging behind the SADC region in terms of green energy development' $\left(F(4,12)=4.93, p=.014, \eta^{2}=.62\right)$. Posthoc analysis showed that people from knowledge

Table 4: Stakeholder opinions on cogeneration in Malawi.

\begin{tabular}{|c|c|c|c|c|c|}
\hline$\overline{\text { Statement }}$ & No. & Mean & $\begin{array}{c}\text { Extent of agree- } \\
\text { ment/disagreement }\end{array}$ & $\begin{array}{l}\text { Standard } \\
\text { deviation }\end{array}$ & \\
\hline Cogeneration is a profitable additional revenue for agro-industries & 4 & 3.98 & 7.42 & 4.24 & \\
\hline $\begin{array}{l}\text { Cogeneration would be a more attractive investment if there was } \\
\text { more open access to the distribution network }\end{array}$ & 12 & 6.06 & 5.34 & 3.37 & \\
\hline $\begin{array}{l}\text { Agro-industries have a duty to improve energy access for local } \\
\text { communities and enterprises }\end{array}$ & 13 & 7.40 & 4 & 6.79 & \\
\hline International finance for low-carbon projects is too difficult to access & 7 & 7.60 & 3.8 & 5.82 & \\
\hline $\begin{array}{l}\text { Malawi is lagging behind the SADC region in terms of green energy } \\
\text { development }\end{array}$ & 11 & 9.92 & 1.48 & 4.90 & \\
\hline $\begin{array}{l}\text { If feed-in tariffs were high enough, cogeneration would have } \\
\text { happened yesterday }\end{array}$ & 8 & 10.33 & 1.07 & 4.55 & 至 \\
\hline Promoters of cogeneration do not have sufficient political support & 14 & 10.79 & 0.61 & 3.45 & क्षّ \\
\hline Insufficient feedstock is a barrier to cogeneration & 3 & 11.02 & 0.38 & 8.26 & \\
\hline Neutral & & 11.40 & 0 & & \\
\hline $\begin{array}{l}\text { Malawi has sufficient skill capacity to take advantage of } \\
\text { opportunities for cogeneration }\end{array}$ & 2 & 13.58 & -2.18 & 5.31 & t. \\
\hline $\begin{array}{l}\text { If feed-in tariffs were high enough, poor people would not be } \\
\text { able to afford electricity }\end{array}$ & 9 & 14.19 & -2.79 & 6.12 & s \\
\hline The policy environment is conducive to scale up green energy & 10 & 14.32 & -2.92 & 5.48 & Ð \\
\hline $\begin{array}{l}\text { Access to cogeneration technology is a barrier to its promotion } \\
\text { in Malawi }\end{array}$ & 1 & 14.84 & -3.44 & 5.91 & \\
\hline Investment in renewable energy is too risky at the moment & 5 & 15.81 & -4.41 & 5.60 & \\
\hline Finance is domestically available for renewable energy investment & 6 & 17.02 & -5.62 & 4.79 & \\
\hline
\end{tabular}


institutions agreed with this statement $(M=5.40$, $S D=3.50)$, while those from government $(M=$ $15.47, S D=0.50)$ and civil society disagreed $(M=$ $13.00, S D=3.54)$

\subsection{Results from focus group discussions and interviews}

Focus group discussions centred on the statements with the most variation in responses in the group, so not all statements were discussed. Follow-up interviews with stakeholders were targeted towards understanding financial and investment issues as they were identified as key issues during the workshop.

\section{Availability of feedstock}

There was a high level of disagreement between individuals over the sufficiency of feedstock for cogeneration (statement 3 had a relatively high standard deviation). Further exploration in the focus group discussions and interviews revealed that, although the absolute amount of biomass available for cogeneration was high in Malawi, participants felt that the availability and the ability to collect these feedstocks economically throughout the entire year (seasonality) were important issues that are yet to be resolved. Possible solutions to seasonality that were discussed included irrigation for double-cropping, the use of alternative feedstocks (residues from sugar, tea and agroforestry were discussed), the use of multiple feedstocks in the same boilers for cogeneration, and using coal in the same boilers when bagasse is unavailable.

\section{Domestic and international finance}

Overall, participants felt that finance for renewable energy was not readily available domestically (statement 6) and that international finance was difficult to access (statement 7). Focus group discussions and interviews on this topic revealed that both agroindustries and local financial institutions have considered investing in cogeneration in Malawi. However, both sources of finance cited the need for extra incentives such as tax breaks and government guarantees to make the investment worthwhile. Although international finance is currently being used in Malawi, several barriers to accessing it were discussed in the focus groups and interviews. These include: the low success rate of funded projects, lack of knowledge about carbon finance, the low baseline for carbon credits in the country, and a lack of direct grants for the private sector. Participants noted that financing was available through development banks, but this reduces the lending portfolio available for other sectors in Malawi. Interviewees identified the lack of appropriate investment structures as one of the major challenges in encouraging cogeneration in agro-industries. One approach that was discussed was the establishment of indepen- dent power producers. New structures for independent power producers are currently being explored through newly commissioned studies in Malawi. One leverage point may be community-scale technologies, such as mini-mills, which can extend the economic zone for collecting sugar-cane as well as provide electricity to surrounding communities.

\section{Feed-in tariff}

The feed-in tariff is important for cogeneration in the sugar industry as it could make installing or upgrading bagasse boilers an attractive investment and improve grid access through supporting legislation. A high feed-in tariff could, however, encourage electricity produced at sugar mills to be fed into the national grid, rather than providing energy to surrounding communities. The level of feed-in tariff was discussed in the focus groups and interviews. Overall, participants felt that feed-in tariffs that were 'high enough' would not have a negative effect on affordability of electricity for the poor (statement 9), but would incentivise cogeneration (statement 8 ). The focus group participants noted that the phrase 'high enough' could point towards a number of different end-goals. That is, the feed-in tariff could be set at a level that is sufficient for investment to occur, for equipment suppliers to enter the market, for the generators to sell into the grid, or for minigrids to be profitable. Some participants felt that a feed-in tariff was warranted as there is a high level of interest in the technology in Malawi and there is already much international experience of the technology (linking with statement 1).

Participants also noted that a high feed-in tariff was not the only necessary condition for cogeneration, but that off-take agreements with the utility were also important (linking with statement 12). Some felt that the delay to the promulgation of the feed-in tariff regulations (which had been in the gazetting process for three years) caused uncertainty for investors. Participants discussed the feed-in tariffs in the context of electricity sector reforms (linking with statement 10). They felt that energy sector reform, such as the unbundling of the electricity sector, could mean better access to the electricity grid for new generators and allow private investment in power generators, including cogeneration from agro-industry facilities. Currently, access to the electricity grid by power generators requires approval by MERA and negotiating a power purchase agreement with Escom. Mini-grids can be established with their own pricing regimes, but approval by MERA is required. At the time of the interviews and group discussions, one mini-grid was under consideration and no new major power generators had been able to successfully negotiate a power purchase agreement for connection to the grid in Malawi. Successful electricity sector reform was seen to be one where the tariff was high 
enough to attract investment, while including social protection measures for the poorest, and to ensure the financial sustainability of the utility.

\section{Discussion}

The results indicate that overall, cogeneration from bagasse has broad stakeholder support in Malawi. There are, however, some pertinent issues around how to facilitate investment in cogeneration that need to be resolved. Although participants do not believe that investment in renewable energy is too risky (statement 5), access to finance is limited and linked to uncertainty in the electricity reform process and feed-in tariff. Returns on investment may also be limited due to the low per capita income levels. At the same time, there is also uncertainty in world sugar prices. In 2017, the current EU sugar regime will come to an end. The overall regulatory environment in Malawi is also challenging for businesses. In 2015, Malawi ranked 164 out of 198 economies on the World Bank's 'Ease of doing business' index (World Bank, 2015). Decisions in electricity sector reform will determine the future role of private investment in Malawi's energy infrastructure. Risks will need to be addressed in order to attract private investment and the final feed-in tariff levels for renewable energy will determine whether electricity from cogeneration will be fed into the national grid or mini-grids serving the local area. These will determine the level of investment in cogeneration by the expanding sugar industry in Malawi and the extent to which this enables energy access in rural areas. One matter that warrants further study is the potential for community-scale installations to contribute to energy access. The findings of this paper are important for countries in sub-Saharan Africa - and others that are considering expanding bagasse cogeneration. Action around bagasse cogeneration cannot be considered in isolation from broader discussions in the energy and sugar sectors.

\section{Conclusions}

Energy access and energy for economic growth remain major challenges in Malawi. Household access to modern energy services is very limited and electricity demand is projected to outstrip planned supply. Malawi has, however, abundant renewable energy resources that could be harnessed to meet the country's growing energy needs. This investigation reviewed the status of the energy sector and sugar industry in Malawi, and showed that cogeneration from bagasse could help meet Malawi's energy demand, especially in rural areas. It further explored the perspectives from stakeholders on the barriers to investment in cogeneration in the sugar industry. It was found that there is enthusiasm for greater participation of agro-industries in renewable energy to enable energy access in rural areas. A series of enabling conditions, however, needs be met to raise the level of investment in cogeneration and include finance, feed-in tariffs and the availability of feedstock at an economically viable level throughout the year. Energy and climate change discourse at the international level are opening up new spaces and resources which could contribute significantly to sustainable development in African countries. These debates need to take into account the economic and regulatory dynamics at the national level, which were illustrated with a case study on cogeneration in the sugar industry in Malawi. The issues affecting investment in clean energy will be increasingly important in the energy and climate change debates as international action on climate change scale-up.

\section{References}

Amigun, B., Musango, J.K. and Stafford, W., 2011. Biofuels and sustainability in Africa. Renewable and Sustainable Energy Reviews 15: 1360-1372. doi:10.1016/j.rser.2010.10.015.

Buchner, B., Stadelmann, M., Wilkinson, J., Mazza, F., Rosenberg, A. and Abramskiehn, D., 2014. The Global Landscape of Climate Finance 2014. Climate Policy Initiative, San Fancisco, Venice, Rio de Janeiro and Jakarta.

Byerlee, D., García, A., Giertz, A., Palmade, V. and Gurcanlar, T., 2013. Growing Africa: Unlocking the potential of agribusiness. World Bank, Washington. DC.

Byrnes, L., Brown, C., Foster, J. and Wagner, L.D., 2013. Australian renewable energy policy: Barriers and challenges. Renewable Energy 60: 711-721. doi:10.1016/j.renene.2013.06.024.

Chirambo, D., 2016. Addressing the renewable energy financing gap in Africa to promote universal energy access: Integrated renewable energy financing in Malawi. Renewable and Sustainable Energy Reviews 62: 793-803. doi:10.1016/j.rser.2016.05.046.

Federation of Southern African Sugar Producers, 2014. Key sugar projects in Southern Africa [WWW Document]. Annu. SADC Sugar Dig. 2014. URL http://www.sadcsugardigest.com/key-sugar-projectsin-southern-africa/ (accessed 3.12.15).

Frankfurt School-UNEP Centre/BNEF, 2014. Global trends in renewable energy investment 2014. Frankfurt School-UNEP Centre and Bloomberg New Energy Finance.

Gamula, G.E.T., Hui, L.and Peng, W., 2013. An overview of the energy sector in Malawi. Energy Power Engineering 5: 8-17.

GNESD, 2007. Renewable energy technologies and poverty alleviation: Overcoming barriers and unlocking potentials. Global Network on Energy for Sustainable Development, Roskilde.

Government of Malawi, 2009. Malawi biomass energy strategy. Government of Malawi, Lilongwe.

Gwede, W., 2016. Malawi MPs fear job cuts at Escom, support electricity Bill to create new companies. Malawi Nyasa Times - Malawi Break. News Malawi. Hassan, S.F., 2008. Development of sugar industry in 
Africa. Sugar Tech 10: 197-203. doi:10.1007/s12355-008-0037-6.

Hudson, A., 2006. Case Study: The reform of the EU's sugar regime (Working Paper). Overseas Development Institute, London.

IRENA, 2016. IRENA Malawi Country Profile [WWW Document]. IRENA Resource URL https://public.tableau.com/views/IRENAREsourceRen ewableEnergyCapacity_CountryProfile/Charts?:embe $\mathrm{d}=\mathrm{y} \&$ :showVizHome $=$ no\&:embed $=\mathrm{y} \&$ :showVizHo $\mathrm{me}=\mathrm{n} \&$ :bootstrapWhenNotified $=\mathrm{y} \&:$ tabs $=\mathrm{n} \&$ :tool bar $=$ n\&allowtransparency $=$ true $\&$ Country $=$ Malawi \&:apiID=handler0 (accessed 7.26.16).

Jimu, C., 2016. Salima sugar factory in k40bn investment. Nation Online.

Karekezi, S., 2016. Status of cleaner energy development in agro-industries of Eastern \& Southern Africa (Working Paper No. 409). Africa Energy Policy Research Network (AFREPREN/FWD), Nairobi.

Lapukeni, P.G.J., 2013. Status of energy policy in Malawi. JICA International Centre.

LMC and ODI, 2012. The impact of EU sugar policy reform on developing countries. LMC International Ltd. and Overseas Development Institute, Oxford \& London.

Luthra, S., Kumar, S., Garg, D. and Haleem, A., 2015. Barriers to renewable/sustainable energy technologies adoption: Indian perspective. Renewable and Sustainable Energy Reviews 41: 762-776. doi:10.1016/j.rser.2014.08.077

Malawi Compact [WWW Document], n.d. . Millennium Challenge Corporation URL https://www.mcc.gov/ pages/countries/program/malawi-compact (accessed 3.18.15)

Malawi Voice, 2016. Reforms on track: Parliament allows unbundling of Escom. Malawi Voice.

Maltsoglou, I., Koizumi, T. and Felix, E., 2013. The status of bioenergy development in developing countries. Global Food Security 2: 104-109. doi:10.1016/j.gfs.2013.04.002

Masera, D. and Couture, T., 2015. Industrial prosumers of renewable energy: Contribution to inclusive and sustainable industrial development. United Nations Industrial Development Organization, Vienna.

Mhango, L.B., 2015. Energy policies and cogeneration in Malawi. In: Agro-Industries and Clean Energy in Africa: Malawi Workshop. Presented at the Agroindustries and Clean Energy in Africa: Malawi Workshop, Lilongwe.

Ministry of Energy and Mining, 2003. National Energy Policy for Malawi. Ministry of Energy and Mining, Lilongwe.

Ministry of Finance \& Development Planning, 2012. Malawi growth and development strategy II: 2011 2016. Ministry of Finance and Development Planning, Government of Malawi, Lilongwe.

Mwase, W.F., Jumbe, C.B.L., Gasc, F., Owiyo, T., Nyaika, J., Kwapata, K., Manduwa, D. andMaonga, B., 2013. Assessment of Agricultural Sector Policies and Climate Change in Malawi - The Nexus between Climate Change Related Policies, Research and Practice. Lilongwe University of Agriculture and Natural Resources \& UN Economic Commission for
Africa, Lilongwe \& Addis Ababa.

National Economic Council, 1998. Malawi Vision 2020: The national long-term development perspective. National Economic Council, Malawi, Lilongwe.

Panagariya, A., 2002. EU Preferential trade arrangements and developing countries. World Economy 25, 1415-1432. doi:10.1111/1467-9701.00499

Phillips, D.P., 2014. Uneven and unequal people-centered development: the case of Fair Trade and Malawi sugar producers. Agriculture Human Values 31, 563-576. doi:10.1007/s10460-014-9500-z

SAPP, 2015. Southern African Power Pool Annual Report 2015. Southern African Power Pool.

Steingass, H., Wentzel, K. and others, 1988. Electricity and ethanol options in southern Africa. US Agency for International Development.

Taulo, J.L., Gondwe, K.J. and Sebitosi, A.B., 2015 Energy supply in Malawi: Options and issues. Journal of Energy in Southern Africa 26: 19-32.

Terazono, E., 2014. Europe's big comeback will shake up sugar. Financial Times.

UN General Assembly, 2012. Resolution adopted by the General Assembly on 21 December 2012: 67/215. Promotion of new and renewable sources of energy.

UNEP, 2013. Emissions reduction profile Malawi. United Nations Environment Programme RISO Centre.

World Bank, Project appraisal document for the Energy Sector Support Project, Malawi, 2011. World Bank.

World Bank, 2015. Doing Business in Malawi - World Bank Group [WWW Document]. Ease of Doing Bussiness URL http://www.doingbusiness.org/ data/exploreeconomies/malawi/ (accessed 3.19.15).

Yaqoot, M., Diwan, P. and Kandpal, T.C., 2016. Review of barriers to the dissemination of decentralized renewable energy systems. Renewable and Sustainable Energy Reviews 58: 477-490. doi:10.1016/j.rser.2015.12.224

Zalengera, C., Blanchard, R.E., Eames, P.C., Juma, A.M., Chitawo, M.L. and Gondwe, K.T., 2014. Overview of the Malawi energy situation and a PESTLE analysis for sustainable development of renewable energy. Renewable and Sustainable Energy Reviews 38: 335-347.

Doi:10.1016/j.rser.2014.05.050. 